\title{
Rates of sediment sulphide oxidation by the bivalve mollusc Thyasira sarsi
}

\author{
P. R. Dando ${ }^{1,2, *}$, A. J. Southward ${ }^{2}$, E. C. Southward ${ }^{2}$ \\ ${ }^{1}$ School of Ocean Sciences, University of Wales Bangor, Menai Bridge LL59 5AB, UK \\ ${ }^{2}$ Present address: Marine Biological Association of the United Kingdom, Citadel Hill, Plymouth PL1 2PB, UK
}

\begin{abstract}
Several bivalve molluscs, including species of Thyasira (family Thyasiridae), use symbiotic sulphur-oxidising bacteria to exploit sulphides in reducing sediments are able to oxidise the insoluble sulphides as well as dissolved sulphide. The behaviour of these bivalves was observed in narrow glass vessels. Rates of sulphide oxidation by Thyasira sarsi (Philippi) were determined in a mesocosm, using specimens and sediment from Oslofjord. The rate of oxidation of reduced sulphur attributable to T. sarsi, $8.7 \mathrm{mmol} \mathrm{d}^{-1} \mathrm{~m}^{-2}$, was close to the rate of sulphide formation in the same sediment, $8.2 \mathrm{mmol} \mathrm{d}^{-1} \mathrm{~m}^{-2}$. This suggests that sulphate reduction rates control density in $T$. sarsi populations. The activities of $T$. sarsi and other lucinaceans can re-oxidise reducing and polluted sediments, allowing colonisation by sulphide-intolerant benthic animals.
\end{abstract}

KEY WORDS: Thyasira sarsi $\cdot$ Sulphide oxidation $\cdot$ Sulphate reduction $\cdot$ Bioturbation $\cdot$ Population density $\cdot$ Ecosystem engineering

\section{INTRODUCTION}

Bacterial sulphate reduction is a major pathway for the mineralization of organic matter in marine sediments (Jørgensen 1989). The sulphide accumulates as iron sulphides and, when available iron has become depleted, free sulphide. Bivalves of the genus Thyasira use their extremely extensible foot to construct deep burrows beneath their shell (Allen 1958, Dando \& Southward 1986) to take up free sulphide from deep in the sediment. The sulphide is utilised by chemoautotrophic, sulphur-oxidising bacteria, housed in the gills of several thyasirids, including Thyasira sarsi (Philippi), and similar symbiotic bacteria occur in other deep-burrowing lucinaceans (Dando \& Southward 1986, Southward 1986). Several other lucinaceans form deep burrows in the sediment below the shell (Stanley 1970). Recently reported experiments (Dufour \& Felbeck 2003) confirm the burrowing behaviour of Thyasira and show that the burrows are deeper where free sulphide levels are low.

Thyasira sarsi reaches a maximum size of $25 \mathrm{~mm}$ and is found in organic-rich shelf sediments along the Nordic coasts from the Kattegat to the Lofotens (Ockelmann
1961). It can reach densities of several thousand $\mathrm{m}^{-2}$ in sewage-enriched sediments (Dando \& Southward 1986) and, with T. flexuosa, is an indicator of organic enrichment (Pearson \& Rosenberg 1978). T. sarsi was formerly rare in the open North Sea, being reported only from natural methane seeps (Dando et al. 1991, 1994a), but has recently colonised oil-containing sediments close to the well heads of North Sea oil rigs (Oliver \& Killeen 2002).

Both Thyasira sarsi and T. flexuosa burrow into soft sediments to a maximum depth of approximately $9 \times$ their shell length, giving a burrowing depth of $180 \mathrm{~mm}$ for a $20 \mathrm{~mm}$ long individual (Dando \& Southward 1986). The thyasirids lack a siphon and use the foot to construct an anterior inhalant canal by cementing sediment particles together with mucus (Allen 1958). Oxygenated water is drawn through this canal, for respiration and heterotrophic feeding, and is then discharged into the sediment. T. sarsi commonly obtains most of its carbon from the symbiotic bacteria (Dando \& Spiro 1993), but it can occur in many habitats where there is no detectable free sulphide (Dando \& Southward 1986). We have carried out experiments to demonstrate how $T$. sarsi can obtain sulphide for its 
symbiotic bacteria in sediments where free sulphide is lacking and to measure the rate at which this bivalve could oxidise insoluble sulphur species in the sediment.

\section{MATERIALS AND METHODS}

Thyasira sarsi collected from the inner Grimstadfjord near Bergen, Norway, were allowed to burrow in $20 \mathrm{~cm}$ tall glass-fronted chambers of $1 \mathrm{~cm}$ width, in which the faceplates were covered by black acrylic slides that could be removed to permit observation. These chambers were filled with sediment from the habitat. Specimens of T. sarsi were placed on top of the sediment and the chambers immersed in a deep tank of circulating seawater at the Marine Biological Association (MBA) laboratory, Plymouth. The observation chambers were removed from the seawater after $5 \mathrm{~d}$ and again after $15 \mathrm{~d}$, the slides lifted and the tunnel structures photographed.

For the study on chemical transformations effected by the bivalves and their symbionts, box cores of sedi- ment were collected on 23 September 1986, using a U.S. Naval Electronics Laboratory design (USNEL) spade-box corer, operated from RV 'Trygve Braarud'. The box cores had an area of $0.222 \mathrm{~m}^{2}$, and a depth of $50 \mathrm{~cm}$, and were taken from $39 \mathrm{~m}$ deep in a known habitat of Thyasira sarsi in Vestfjorden, Oslofjord, Norway $\left(59^{\circ} 47.01^{\prime} \mathrm{N}, 10^{\circ} 30.87^{\prime} \mathrm{E}\right)$. The station was in a slight depression with a $15 \mathrm{~m}$ high rock sill to the south. All the box cores were taken in the same position on the same day. The retrieved cores, in PVC liners, were placed in flowing seawater in the mesocosm facility at the Norsk Institut for Vannforskning (NIVA), Solbergstrand. Seawater, at $11.0 \pm 0.9^{\circ} \mathrm{C}$, was pumped into the mesocosm tank from $45 \mathrm{~m}$ depth in Oslofjord, and there was $1 \mathrm{~m}$ of water above the top of the box cores. Daylight was excluded. PVC tubes (150 mm long, $103 \mathrm{~mm}$ internal diameter) were pressed into each experimental box core to form subcores. The top of the tube was temporarily fitted with a transparent stopper through which a slight vacuum was applied as the tube was very slowly pressed into the sediment until only a few mm protruded (Fig. 1b,c).

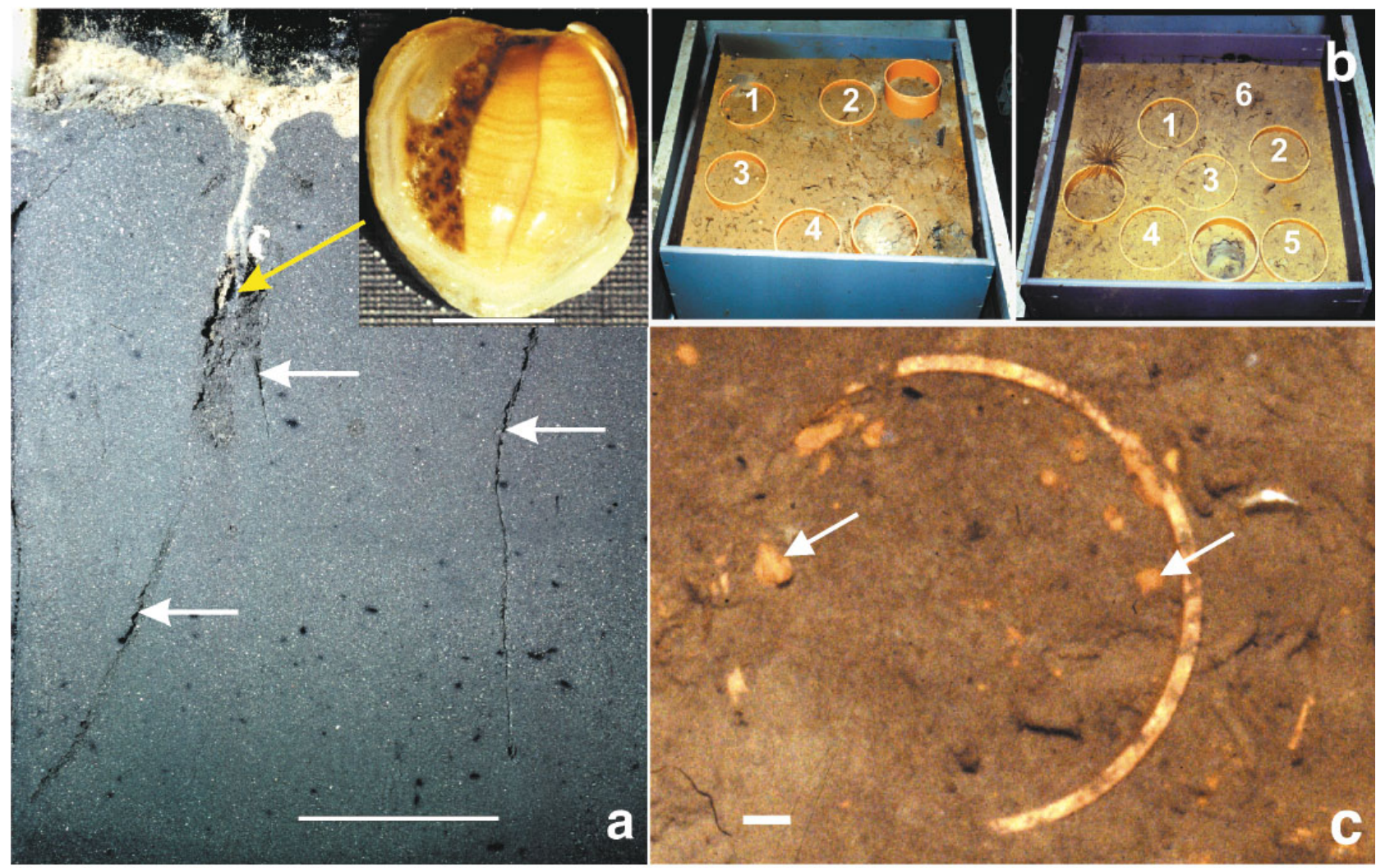

Fig. 1. Tanks and cores containing Thyasira sarsi. (a) Tunnel systems formed in the sediment by T. sarsi after $15 \mathrm{~d}$ : tunnels below the bivalve (white arrows); oxidation of the sediment reveals the position of the vertical inhalant tube (yellow arrow). Inset is a specimen with the left valve removed, showing the sulphur-laden gills (scale bar $=10 \mathrm{~mm}$ ). (b) Box Cores 1 (left) and 2 (right) during the experiment, showing numbered subcores (subcores that are not numbered were not used in this study). A glass bottle was found in the centre of Box Core 1 when it was recovered and this part of the core was not used. (c) Close-up of one insert showing the mounds of hydrated iron (arrowed) over the exhalent streams from the bivalves (scale bar $=10 \mathrm{~mm}$ ) 
This slight vacuum prevented compression of the sediment and minimised disturbance during tube insertion. The sediment was not otherwise disturbed and no attempt was made to kill or remove existing fauna. However, the sediment disturbance resulting from placing the box cores in the mesocosm and inserting the tube sections caused some thyasirids to come to the surface during the $2 \mathrm{~d}$ following the disturbance. These bivalves subsequently burrowed into the sediment again. Sediment from one of the box cores was sieved to obtain live $T$. sarsi; 8 of the freshly removed individuals were immediately dissected for measurement of elemental sulphur (Fliermans \& Brock 1973). A total of 90 live bivalves with no visible shell damage were sorted into 3 groups of 10 and 3 groups of 20, with assorted sizes in each group. These groups were added to randomly chosen sub-cores (Table 1) in an attempt to change the densities of the bivalve in the core sections to values equivalent to approximately 1000 or 2000 T. sarsi m ${ }^{-2}$. The final number of individuals present could not be determined until the end of the experiment, since some of the added thyasirids may have died after burrowing, others may have moved over the shallow core lip before burrowing and there was an unknown number in each core section originally. We found that there had been a high mortality in, or migration from, the densely stocked subcores (Table 1).

After $30 \mathrm{~d}$ the tubes were removed and the subcores sectioned into 15, 20 or $30 \mathrm{~mm}$ slices. The sediment sections were pushed out of the subcore tubes into argon-filled bags, which were kneaded to homogenise the sediment before chemical sampling. Pore water was obtained by pressure filtration through cellulose acetate filters of $0.2 \mu \mathrm{m}$ porosity. Bivalves were removed from the sediment by washing on a sieve of $1 \mathrm{~mm}^{2}$ mesh. Dissolved sulphide was determined by

Table 1. Thyasira sarsi. Number of individuals added to each subcore in the mesocosm experiment. The original number of T. sarsi in each subcore was unknown. The number recovered by sieving the sediment at the end of the $30 \mathrm{~d}$ study is shown in the final column

\begin{tabular}{|cccc|}
\hline Box core & Subcore & No. added & No. after $30 \mathrm{~d}$ \\
\hline 1 & 1 & 10 & 14 \\
1 & 2 & 20 & 11 \\
1 & 3 & 0 & 5 \\
1 & 4 & 0 & 2 \\
2 & 1 & 10 & 16 \\
2 & 2 & 20 & 15 \\
2 & 3 & 20 & 16 \\
2 & 4 & 10 & 17 \\
2 & 5 & 0 & 1 \\
2 & 6 & 0 & 4 \\
\hline
\end{tabular}

colorimetry (Cline 1989) and sulphate by HPLC. Sediment sub-samples were extracted with hexane and the evaporated extracts were analysed for elemental sulphur (Fliermans \& Brock 1973). Acid-labile sulphide and chromous-reducible sulphide were then determined by reducing the sulphur to hydrogen sulphide in stages (Zhabina \& Volkov 1978) and measuring the sulphide by colorimetry (Cline 1989). Sulphate reduction rates were determined by injection of ${ }^{35} \mathrm{~S}$-sulphate into $3 \mathrm{ml}$ subcores, which were incubated at $10^{\circ} \mathrm{C}$ for $19 \mathrm{~h}$ (Dando et al. 1991). pH was measured to $\pm 0.1 \mathrm{pH}$ unit with a combination electrode calibrated with National Bureau of Standards (NBS) buffers. Sampling + analytical precision was $\pm 2 \%$ for dissolved sulphide, $\pm 1 \%$ for sulphate, $\pm 5 \%$ for insoluble sulphur species and $\pm 10 \%$ for sulphate reduction.

\section{RESULTS}

The nature of sediment modification by Thyasira sarsi was shown by the specimens placed in the narrow chambers containing reduced sediment from their habitat (Fig. 1a). Within 5 d, the sediment surrounding the inhalant canals was paler and tunnels were obvious in the sediment deep below the position of the shell. After $15 \mathrm{~d}$ the sediment around the inhalant canals was yellow, indicating that the particulate iron sulphides in the surrounding sediment had been oxidized.

Quantification of the effect of the bivalves on the sediment was provided by the experiments in Norway, where freshly collected specimens of Thyasira sarsi were added to subsections of box cores (see 'Materials and methods'). The interstitial water in the upper $50 \mathrm{~cm}$ of sediment contained less than $0.1 \mu \mathrm{M}$ total dissolved sulphide; $90 \%$ of the T. sarsi were in the upper $50 \mathrm{~mm}$ (Table 2). Before additional specimens were added, the box core sediment contained T. sarsi at a density equivalent to $411 \mathrm{~m}^{-2}$ and specimens were in the size range of 2.7 to $8.5 \mathrm{~mm}$ shell length, mean

Table 2. Thyasira sarsi. Number of individuals found at different sediment depths in the subcores

\begin{tabular}{|crc|}
\hline Sediment depth $(\mathrm{cm})$ & Box Core 1 & Box Core 2 \\
\hline $0-1.5$ & 7 & 21 \\
$1.5-3.0$ & 16 & 26 \\
$3.0-5.0$ & 6 & 14 \\
$5.0-7.0$ & 2 & 5 \\
$7.0-9.0$ & 0 & 0 \\
$9.0-12.0$ & 1 & 0 \\
$12.0-14.5$ & 0 & 1 \\
\hline
\end{tabular}


$5.2 \pm 1.8$ (SD) mm. The 10 experimental subcores were divided into 2 groups for data analysis; 4 subcores formed the 'low-density' group with 1 to $5 \mathrm{~T}$. sarsi per core (mean: 3.3 T. sarsi per subcore, equivalent to $333 \mathrm{~m}^{-2}$ ) and 6 subcores formed the 'high-density' group with 11 to 17 T. sarsi per core (mean: 14.7, equivalent to $1630 \mathrm{~m}^{-2}$ ).

The $\mathrm{pH}$ of the expressed interstitial water (Fig. 2a) was lower in the 'high-density' group at all 7 sediment depth levels examined (sign test, $\mathrm{p}<0.01$ ). The greatest decrease, from a mean of $\mathrm{pH} 7.39$ to a mean of $\mathrm{pH}$ 6.52, was in the top $15 \mathrm{~mm}$ layer. Acid-labile sulphide (mainly FeS) and chromous-reducible sulphide $\left(\mathrm{FeS}_{2}\right)$ concentrations were less at all depths in the 'high-density' subcores compared with the 'lowdensity' subcores $(\mathrm{p}<0.01)$. With the exception of the 5 to $7 \mathrm{~cm}$ depth section the elemental sulphur concentrations were always lower in the 'high-density' group $(p<0.016)$. At the bottom of the subcores, below $12 \mathrm{~cm}$ depth, the concentrations of reduced sulphur species converged in the 2 groups (Fig. 2b). A cumulative plot of the total insoluble reduced sulphur (Fig. 2c) showed that the 'high-density' subcores had a mean reduced sulphur content, to $14 \mathrm{~cm}$ depth in the core, of

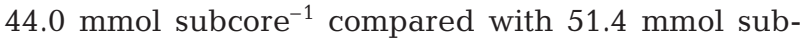
core $^{-1}$ for the 'low-density' subcores. This difference, of $7.4 \mathrm{mmol}$ core $^{-1}$, in subcores with an average of 11.7 more Thyasira sarsi, equals loss from the sediment, of $21.3 \mu \mathrm{mol}$ reduced sulphur $\mathrm{d}^{-1}$ for every T. sarsi. This is equivalent to a loss of $8.7 \mathrm{mmol}$ of reduced $\mathrm{S} \mathrm{d}^{-1} \mathrm{~m}^{-2}$ at the density of $411 \mathrm{~T}$. sarsi $\mathrm{m}^{-2}$ at the study site in Oslofjord.

Sulphate reduction rates were determined over the upper $14 \mathrm{~cm}$ of sediment of the 'low-density' Subcore 2-6, containing 4 Thyasira sarsi. The integrated rate was equivalent to $8.2 \mathrm{mmol}$ sulphate reduced $\mathrm{d}^{-1} \mathrm{~m}^{-2}$. The rate was fairly uniform throughout the subcore, with the exception of the partially oxidised upper $15 \mathrm{~mm}$ (Fig. 3). Reduction rates were determined on 2 sections of a 'high-density' core (2-1) containing 16 T. sarsi. The similarity of rates at 5 to $9 \mathrm{~cm}$ sediment depth (Fig. 3), $0.067 \mathrm{mmol}$ sulphate reduced $\mathrm{dm}^{-3}$ sediment $\mathrm{d}^{-1}$ for the 'low-density' core and 0.065 to $0.073 \mathrm{mmol}$ sulphate reduced $\mathrm{dm}^{-3}$ sediment $\mathrm{d}^{-1}$ for the 'high-density' core, suggests that increasing the number of bivalves did not substantially alter the rate of sulphide formation.

The gills contained up to $37.8 \pm 14.4$ (SD) $\mu \mathrm{mol}$ elemental sulphur $\mathrm{g}^{-1}$ wet wt of gill tissue, with the highest concentrations being found in the largest bivalves and in bivalves with the highest ratios of (gill weight):(total tissue body weight) (Fig. 4). Elemental sulphur was not found in non-gill tissues, nor was it found in gill or non-gill tissues of other bivalves in this sediment (data not shown).
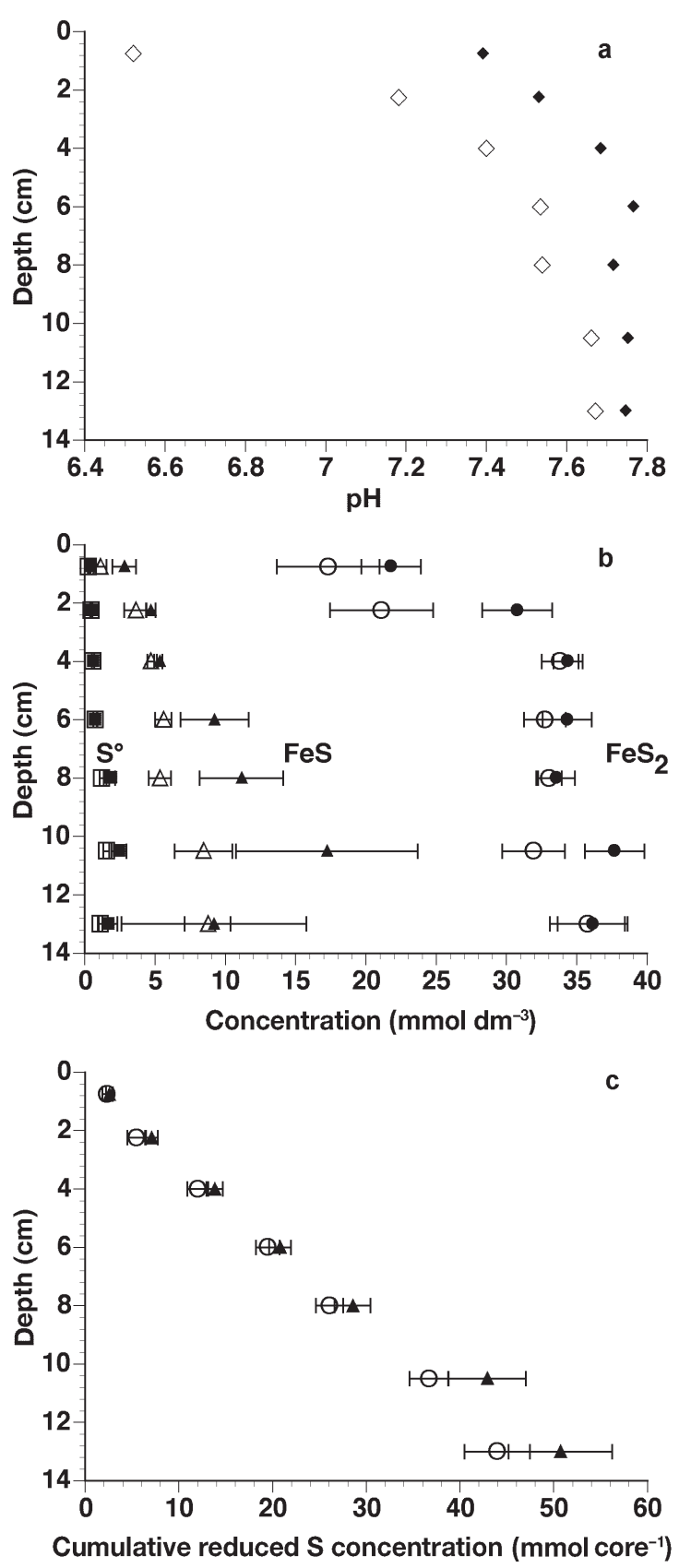

Fig. 2. Sediment chemistry profiles for subcores with Thyasira sarsi. Solid symbols: 'low' numbers (1 to 5 ind.); open symbols 'high' numbers (11 to 17 ind.). (a) Mean pH. (b) Concentrations of insoluble reduced sulphur, elemental sulphur $\left(\mathrm{S}^{0}\right)$ (squares), acid labile sulphide (FeS) (triangles), and chromous reducible sulphide $\left(\mathrm{FeS}_{2}\right)$ (circles); all data are mean $\pm \mathrm{SE}$. (c) Cumulative concentration, with depth, of reduced sulphur in the core tubes $\left(\mathrm{S}^{0}+\mathrm{FeS}+\mathrm{FeS}_{2}\right)$; mean $\pm \mathrm{SE}$

\section{DISCUSSION}

Thyasira sarsi normally obtain much of their nutrition from the endosymbiotic sulphur-oxidising bacteria in their gills. The gills are cream-coloured from de- 


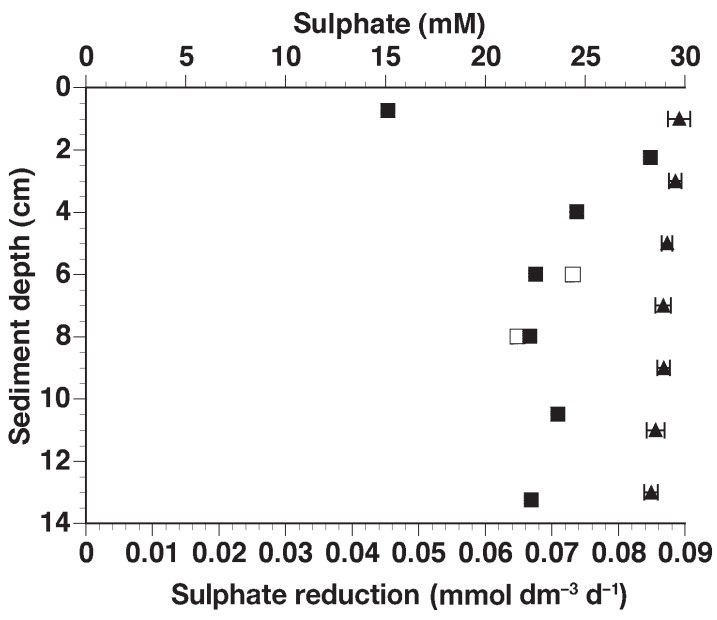

Fig. 3. Sediment sulphate reduction rates (squares) and interstitial water sulphate concentrations (triangles) in Subcores 2-6 (closed symbols) and 2-1 (open symbols)

position of elemental sulphur in invaginations of the bacterial membranes. T. sarsi from methane seep habitats and from very organic-rich fjord sediments, where free sulphide is readily available, have tissues that are highly depleted in ${ }^{13} \mathrm{C}$, showing $\delta^{13} \mathrm{C}$ values of -31 to $-39.5 \%$ (Spiro et al. 1986, Schmaljohann et al. 1990, Dando et al. 1991, Dando \& Spiro 1993), indicating that most of their nutrition comes from the endosymbiotic bacteria. The most depleted value found for non-methane seep sediments was $-34 \%$ $\delta^{13} \mathrm{C}$. Lower $\delta^{13} \mathrm{C}$ values in animals collected around methane seeps probably resulted from some of the inorganic carbon fixed being derived from highly ${ }^{13} \mathrm{C}$-depleted methane. Detailed electron microscopy studies (Schmaljohann 1991) have provided no evidence that $T$. sarsi close to methane seeps has a dual symbiosis of methanotrophic symbionts as well as sulphur-oxidising symbionts, unlike the situation in some species of Bathymodiolus (Fiala-Médioni et al. 2002).

In sediments in which there was no odour of hydrogen sulphide and where it could not be detected by colorimetry (i.e. concentration $<0.1 \mu \mathrm{M}$; Dando et al. 1985), the ${ }^{13} \mathrm{C}$ content of Thyasira sarsi tissues was much higher. In some specimens it approached the values found in heterotrophic bivalves in the same sediment, -17.4 to $-17.1 \% \delta^{13} \mathrm{C}$ (Dando \& Spiro 1993). This implies a lesser dependence on organic carbon supplied by the endosymbionts to $T$. sarsi in such sediments. The T. sarsi from the Oslofjord sediment used in this study had mean tissue $\delta^{13} \mathrm{C}$ values of -22.4 to $-24.0 \%$ (Dando \& Spiro 1993). If we assume a $\delta^{13} \mathrm{C}$ of $-18 \%$ for heterotrophic bivalves in the fjord and a value of $-34 \%$ for a $T$. sarsi entirely dependent on endosymbionts for nutrition, then these Oslofjord bivalves are obtaining between 27.5 and $37.5 \%$ of their tissue carbon from the bacteria. The gills of all but one of the $T$. sarsi specimens examined contained elemental sulphur, confirming that reduced sulphur species were being taken up. The increasing elemental sulphur content with increasing shell size (Fig. 4) was probably related to the deeper burrowing capability of the larger individuals and hence their access to greater amounts of reduced sulphur.

The above evidence indicates that the sulphuroxidising endosymbiotic bacteria in this Oslofjord population of Thyasira sarsi contributed significantly to their nutrition. A response of T. sarsi to low free sulphide in the sediment is to extend the length and depth of the burrow below the shell to access higher concentrations of sulphide (Dufour \& Felbeck 2003). However, such burrows are limited to a maximum depth of $30 \times$ the shell length, which would be $255 \mathrm{~mm}$ in the pre-
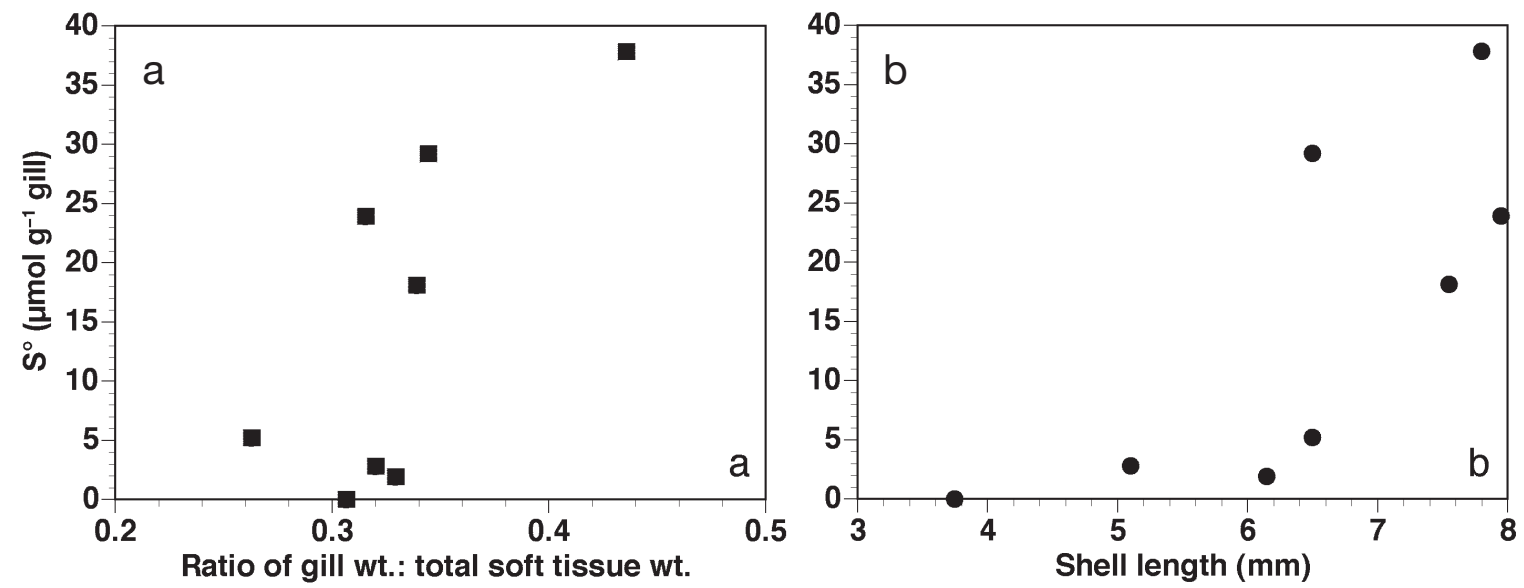

Fig. 4. Thyasira sarsi. Elemental sulphur content of the gills, showing the variation with (a) relative gill weight, (b) shell length 
sent study, and free sulphide was still undetectable at $500 \mathrm{~mm}$ depth in our sediment samples. This suggested that, as described for Lucinoma borealis (Dando et al. 1994b), T. sarsi are able to 'mine' the insoluble sulphur species in the sediment by drawing oxygenated water through a semi-permeable inhalant tube. The results of the mesocosm experiment demonstrated that adding $T$. sarsi to otherwise undisturbed sediment lowered the concentrations of acid-labile sulphide, chromous-reducible sulphide and elemental sulphur in the sediment above the bivalves. The overall reduction in insoluble reduced sulphur resulting from activity of $T$. sarsi in the sediment was equivalent to $8.7 \mathrm{mmol}$ of reduced $\mathrm{S} \mathrm{d}^{-1} \mathrm{~m}^{-2}$.

The rate of sulphide formation in the mesocosm experiment was $8.2 \mathrm{mmol} \mathrm{d}^{-1} \mathrm{~m}^{-2}$. Although sulphate reduction determinations were only made on 2 subcores, the rate was identical, within measurement error, to the rate of removal of reduced sulphur by Thyasira sarsi. We suggest that this similarity is not coincidental, but that the sulphate reduction rate of sediment determines the maximum sustainable density of symbiontcontaining thyasirids.

At the $39 \mathrm{~m}$ site in Vestfjorden the bottom water does not become deoxygenated, defaunation does not occur and thyasirid densities are relatively stable (Aschan \& Skullerud 1990). In contrast, at fjord sites where the bottom water can become deoxygenated there are large variations in thyasirid densities (Dando \& Spiro 1993). At such places, the pulse of dead organic matter added to the sediment following infaunal death, plus the deoxygenation of the bottom water, increases the sulphate reduction rate. When oxygenated water is introduced, a large thyasirid population rapidly becomes established and the rate of sulphide oxidation by this population will exceed the declining sulphate reduction rate. Under these conditions sediment sulphides are rapidly depleted. When sulphide sources are low, some of the thyasirids can exist heterotrophically for a period (Dando \& Spiro 1993).

As with other lucinaceans (Dando et al. 1994b), pumping oxygenated water through the semi-permeable inhalant tube results in rapid oxidation of the iron sulphides in the surrounding sediment. Disproportionation of the thiosulphate that is formed under these conditions results in free sulphide becoming available and diffusing back into the tube. The thyasirids also have a posterior inhalant aperture that draws water directly from the sediment onto the gills (Allen 1958). The fluid flows induced in the tunnels (Oliver \& Killeen 2002) and by 2 inhalant streams (Allen 1958) will produce a considerable passage of water through the sediment, increasing the oxidation and removal of sulphur species. The very slight depletion of sulphate with depth in cores with few Thyasira sarsi, i.e. with low sulphide oxidation rates despite the high sulphate reduction rate (Fig. 3), provides additional evidence for enhanced fluid flow and re-oxidation of sulphides. Sulphuric acid, excreted by the sulphur-oxidising bacteria in the gills, will be expelled into the sediment in the exhalant water stream, further increasing solubilisation of the sulphides.

Symbiont-containing thyasirids are secondary colonisers of organic-rich sediments, coming after capitellid polychaetes that feed directly on bacteria (Pearson $\&$ Rosenberg 1978). The thyasirids are in turn followed by the larger lucinids. The term 'ecosystem engineer' has been applied to those organisms that modulate the availability of resources to other species (Mitsch \& Jörgensen 1989, Jones et al. 1994). The activities of the thyasirids reported here would qualify them as ecosystem engineers of the allogenic type (Jones et al. 1994). It has been suggested that large aggregations of symbiont-containing perviate and obturate pogonophorans likewise can modify the sediment chemistry (Southward \& Dando 1988, Cordes et al. 2003), albeit on a much slower time scale. The activity of the symbiont-containing bivalves in irrigating sediments removes toxic hydrogen sulphide and creates conditions for the successful colonisation of the sediment by heterotrophic species. This natural response of the ecosystem might well be exploited to regenerate organically polluted sediments. Bioturbation by later burrowers, such as polychaetes, crustaceans and infaunal echinoderms that follow the bivalves, will disrupt the tunnel systems, decreasing the ability of the bivalves to obtain sulphide. This helps to explain why Thyasira sarsi, T. flexuosa and other lucinaceans are most abundant in sediments with an otherwise sparse infauna (Allen 1958).

Acknowledgements. The work in Norway was partly financed by the UK Natural Environment Research Council through the Marine Biological Association. A.J.S. is indebted to the Leverhulme Trust for financial support during part of this study. We thank the crew of the research vessel 'Trygve Braarud' for help in collecting the box core samples in Oslofjord; T. Bakke, NIVA, for use of mesocosm facilities at the Marine Research Station Solbergstrand, J. Gray for introducing P.R.D. to the Oslofjord habitats and for assistance in arranging facilities; P. J. Johannessen and the crews of the research vessels 'August Brinkmann DE' and 'Knurr' (University of Bergen) for help in obtaining specimens from Grimstadfjord; R. Barrett, S. O'Hara and R. Ling for help in sediment analysis, and D. Nicholson for tunnel system photography.

\section{LITERATURE CITED}

Allen JA (1958) On the basic form and adaptation to habitat in the Lucinacea (Eulamellibranchia). Phil Trans R Soc Lond B 241:421-484

Aschan MM, Skullerud AM (1990) Effects of changes in 
sewage pollution on soft-bottom macrofauna communities in the inner Oslofjord, Norway. Sarsia 75:169-190

Cline JD (1989) Spectrophotometric determinations of hydrogen sulphide in natural waters. Limnol Oceanogr 14: $454-458$

Cordes EE, Bergquist DC, Shea K, Fisher CR (2003) Hydrogen sulphide demand of long-lived vestimentiferan tubeworm aggregations modifies the chemical environment at deep-sea hydrocarbon seeps. Ecol Lett 6:212-219

Dando PR, Southward AJ (1986) Chemoautotrophy in bivalve molluscs of the genus Thyasira. J Mar Biol Assoc UK 66: 915-929

Dando PR, Spiro B (1993) Varying nutritional dependence of the thyasirid bivalves Thyasira sarsi and T. equalis on chemoautotrophic symbiotic bacteria, demonstrated by isotope ratios of tissue carbon and shell carbonate. Mar Ecol Prog Ser 92:151-158

Dando PR, Southward AJ, Southward EC, Terwilliger NB, Terwilliger RC (1985) Sulphur-oxidising bacteria and haemoglobin in gills of the bivalve mollusc Myrtea spinifera. Mar Ecol Prog Ser 23:85-98

Dando PR, Austen MC, Burke RJ, Kendall MA and 6 others (1991) Ecology of a North Sea pockmark with an active methane seep. Mar Ecol Prog Ser 70:49-63

Dando PR, Bussmann I, Niven SJ, O'Hara SCM, Schmaljohann R, Taylor LJ (1994a) A methane seep area in the Skagerrak, the habitat of the pogonophore Siboglinum poseidoni and the bivalve mollusc Thyasira sarsi. Mar Ecol Prog Ser 107:157-167

Dando PR, Ridgway SA, Spiro B (1994b) Sulphide 'mining' by lucinid bivalve molluscs:demonstrated by stable sulphur isotope measurements and experimental models. Mar Ecol Prog Ser 107:169-175

Dufour SC, Felbeck H (2003) Sulphide mining by the superextensile foot of symbiotic thyasirid bivalves. Nature 426 : 65-67

Fiala-Médioni A, McKiness ZP, Dando P, Boulegue J, Mariotti A, Alayse-Danet AM, Robinson JJ, Cavanaugh CM (2002) Ultrastructural, biochemical, and immunological characterization of two populations of the mytilid mussel Bathymodiolus azoricus from the Mid-Atlantic Ridge: evidence for a dual symbiosis. Mar Biol 141:1035-1043

Editorial responsibility: Otto Kinne (Editor),

Oldendorf/Luhe, Germany
Fliermans CB, Brock TD (1973) Assay of elemental sulphur in soil. Soil Sci 115:120-122

Jones CG, Lawton JH, Shachak M (1994) Organisms as ecosytem engineers. Oikos 69:373-386

Jørgensen BB (1989) Sulfate reduction in marine sediments from the Baltic Sea-North Sea transition. Ophelia 31:1-15

Mitsch WJ, Jörgensen SE (eds) (1989) Ecological engineering: an introduction to ecotechnology. John Wiley, New York

Ockelmann WK (1961) The status of Thyasira insignis, T. plana and T. inaequalis, all Verril and Bush. Nautilus 75:50-55

Oliver PG, Killeen IJ (2002) The Thyasiridae (Mollusca: Bivalvia) of the British continental shelf and North Sea oil fields. Identification manual. BIOMÔR Reports 3. National Museum and Galleries of Wales, Cardiff

Pearson TH, Rosenberg R (1978) Macrobenthic succession in relation to organic enrichment and pollution of the marine environment. Oceanogr Mar Biol Annu Rev 16:229-311

Schmaljohann R (1991) Unusual ultrastructure of bacterial endosymbionts in the bivalve Thyasira sarsi from Central Skagerrak. Kiel Meeresforsch 8:240-244

Schmaljohann R, Faber E, Whiticar MJ, Dando PR (1990) Co-existence of methane- and sulphur-based endosymbioses between bacteria and invertebrates at a site in the Skagerrak. Mar Ecol Prog Ser 61:119-124

Southward AJ, Dando PR (1988) Distribution of Pogonophora in canyons in the Bay of Biscay: factors controlling abundance and depth range. J Mar Biol Assoc UK 68:627-638

Southward EC (1986) Gill symbionts in thyasirids and other bivalve molluscs. J Mar Biol Assoc UK 66:889-914

Spiro B, Greenwood PB, Southward AJ, Dando PR (1986) ${ }^{13} \mathrm{C} /{ }^{12} \mathrm{C}$ ratios in marine invertebrates from reducing sediments:confirmation of nutritional importance of chemoautotrophic endosymbiotic bacteria. Mar Ecol Prog Ser 28: 233-240

Stanley SM (1970) Relation of shell form to life habits of the Bivalvia (Mollusca). Mem Geol Soc Am 125:1-193

Zhabina NN, Volkov II (1978) A method of determination of various sulphur compounds in sea sediments and rocks. In: Krumbein WE (ed) Environmental biogeochemistry and geomicrobiology, Vol 3. Ann Arbor Scientific Publishers, Ann Arbor, MI, p 735-746

Submitted: March 4, 2004; Accepted: June 29, 2004

Proofs received from author(s): October 1, 2004 